\title{
The Law and Politics of Religion and Constitutional Practices in Asia
}

\author{
Dian A H SHAH* \\ Faculty of Law, National University of Singapore, Singapore \\ dian.ahshab@nus.edu.sg
}

In January 201 8, the Federal Court of Malaysia issued a landmark judgment in Indira $G a n d h i^{\mathrm{I}}$ - a case that epitomized a protracted battle not only about the boundaries of religious freedom in Malaysia, but also about the role of the (civil) courts in adjudicating important constitutional questions that are bound up with religious matters. Indira Gandhi is a mother of three children who were converted to Islam without her knowledge - by her then husband, who embraced Islam at some point during their marriage. The children had been born and raised in the Hindu faith, and Indira's marriage to her husband was contracted under the civil law applicable to nonMuslims. ${ }^{2}$ In 2009, immediately upon discovering her children's conversion, Indira challenged the validity and legality of the conversion, and in a separate suit, she subsequently obtained custody of her three children. Her husband, however, had earlier secured custody of the children through the shariah courts. All these marked the start of an almost decade-long legal battle revolving around a mother's quest to secure custody of her children and seek an equal say in crucial decisions relating to the upbringing of her children.

Although the Indira Gandhi case might strike us as a private, family dispute, it is riddled with questions about constitutional interpretation and what is treated - in practice - as the 'constitution' in cases implicating religion. Does Article I 2(4) of the Federal Constitution of Malaysia I957 (Federal Constitution), which cements parental rights over a minor's choice of religion, require both parents to consent to the conversion of a minor? Does Article I2 I(IA) of the Federal Constitution, which strips the civil courts of jurisdiction in matters within the shariah court's jurisdiction, mean that every issue implicating Islam (even when it overlaps with questions concerning

\footnotetext{
* $\quad$ LLB (Warwick), LLM (Duke), SJD (Duke). Assistant Professor, Faculty of Law, National University of Singapore. I would like to thank Associate Professor Dan Puchniak (Director of the Centre for Asian Legal Studies), Dr Mario Gomez (Executive Director of the International Centre for Ethnic Studies), Mrs Gisela Elsner (Director of the Rule of Law Programme Asia, Konrad-Adenauer-Stiftung), as well as the CALS and ICES staff for their support and assistance in organizing the 'Religion and Constitutional Practices in Asia' conference in Colombo. I am also grateful for the generous financial support from CALS, and for the invaluable contributions of participants at the conference.

I. Indira Gandhi a/p Mutho v Pengarah Jabatan Agama Islam Perak [2018] I MLJ 545 (Federal Court).

2. Law Reform (Marriage and Divorce) Act I976 (Act I64).
} 
constitutional rights and constitutional interpretation) is beyond the reach of the civil courts? Where does the constitution's basic structure factor into constitutional interpretation and constitutional practice, and how does that shape conceptions about the role of the judiciary in a constitutional democracy?

Aside from these questions, cases like Indira Gandhi - and those presented in this Special Issue, as we will see - are entangled with broader political questions in plural societies, especially societies where religion is not only a matter of personal identity and conviction, but also deeply embedded in social and political life. How are the disagreements and political concerns of different groups embedded and expressed in key cases implicating religion? What factors might shape the outcomes of majorityminority contests implicating religion?

In Indira Gandhi, what lurked beneath the case were concerns about 'protecting' the authority and exclusivity of Islamic institutions, derived from a peculiar conception of what it means to have Islam as the 'state religion'. This then implicates concerns about religious pride and preserving the dominance of the majority ethno-religious group (ie, the Malay-Muslims), which is often - though not exclusively - viewed in terms of numerical strength. These considerations raise further questions: to what extent does the dominant religion, or considerations about religion more generally, drive the prevailing constitutional discourse and practices in a country? Do formal constitutional arrangements on religion matter, and if so, how and when do they matter?

The Federal Court's judgment in Indira Gandhi is therefore significant for a number of reasons. First, the Court held that the Federal Constitution mandates that the conversion of minors require the consent of both parents. ${ }^{3}$ This reverses the longheld position that the word 'parent' in Article I 2(4) of the Federal Constitution is to be construed in the singular - a position that has proven to be problematic as it neglects the right of the other parent (who, in cases of unilateral conversion of minors, tends to be the mother) to determine the child's religion. ${ }^{4}$ This has to be considered in the context of the concurrent operation of civil and shariah jurisdictions, which is not problematic in and of itself, but it is complicated by the tendency of the civil courts to defer jurisdiction to shariah courts when a matter implicates Islam or Islamic law. ${ }^{5}$

However, even on this thorny issue of the judicial powers of the civil courts, the Federal Court in Indira Gandhi took a different path. In fact, the issue was the crux of the Court's roo-page judgment. Stressing the role of the judiciary in upholding the rule

3. Indira Gandhi (n I) 603. The Court held that conversion is 'a momentous decision affecting the life of a child' and under such circumstances, it is 'undoubtedly in the best interests of the child that the consent of both parents must be sought'.

4. See for eg, Subashini a/p Rajasingam $v$ Saravanan all Thangathoray [2008] 2 MLJ I47 (Federal Court); Pathmanathan Krishnan v Indira Gandhi Mutho [20I6] I CLJ 9I I (Court of Appeal).

5. See for eg, Lina Joy v Majlis Agama Islam Wilayah Persekutuan [2007] 4 MLJ 585 (Federal Court); Pathmanathan all Krishnan (also known as Muhammad Riduan bin Abdullah) $v$ Indira Gandhi a/p Mutho [2016] 4 MLJ 455 (Court of Appeal); Kassim @ Osman bin Ahmadv Dato’ Seri Jamil Khir bin Baharom, Menteri di Jabatan Perdana Menteri (Hal Ehwal Agama Islam) [2016] 7 MLJ 669 (High Court). 
of law, the Court held that judicial review is an 'essential feature of the basic structure of the Constitution'. ${ }^{6}$ As such, Article I2 I(IA) of the Federal Constitution does not affect the inherent judicial powers of the civil courts to interpret and enforce the Federal Constitution and to review the legality of the State's exercises of power. ${ }^{7}$ In the context of Indira's case, the Federal Court essentially took the bull by its horns - that notwithstanding the religious implications of the case, the Court remains empowered to review the legality and constitutionality of a public authority's administrative action (in this case, the Registrar of Muallaf's decision to issue the Certificates of Conversion for Indira's children). ${ }^{8}$

In many ways, the Indira Gandhi case captures the myriad issues arising from the interaction between constitutional law, religion, and politics in the different contributions in this Special Issue. At its core, the overall research underpinning this Issue aims to uncover how constitutional arrangements implicating religion are practiced, lived, and understood in society and in governance. Aside from illustrating what is treated in practice as the 'constitution' when it comes to disputes or issues involving religion, the articles highlight the impact of constitutional recognition of religion (or non-recognition, as the case may be), as well as the implications of religion on constitutional law and development.

For one, the case studies in this Special Issue encourage us to reflect on the relationship between religion, constitutional democracy, and the rule of law. In what ways does religion support or stifle constitutionalism? Thailand, for instance, sees itself as in essence a constitutional democracy. Yet, the influence of Buddhist social and political hierarchies remains salient. The King - whose role since ancient times is tied to preserving Buddhism - is not always bound by the constitution; instead, he is constrained by the dhamma (a form of natural law principles) and the doctrine of the dhammarāja (the righteous King). ${ }^{9}$ Therefore, although Buddhism is not a state religion in Thailand, it shapes and informs constitutional thought and practice through the concept of the Buddhist Kingship.

One might also discover parallels in Gehan Gunatilleke's contribution, which examines how and why ethno-religious violence has become entrenched in Sri Lanka's constitutional practice. ${ }^{\text {IO }}$ As in Thailand, the Constitution of Sri Lanka 1978 (I978 Constitution) does not enshrine a state religion, but it accords a privileged position to Buddhism. Highlighting evidence of both tacit government support of, and

6. Indira Gandhi (n I) 573. Interestingly, the Court also noted three principles in a Westminster-model constitution (such as the Federal Constitution) that are part of the basic structure of the constitution: (I) the separation of powers; (2) the rule of law; and $(3)$ the protection of minorities. ibid 583 .

7. ibid 576. Art I2I(IA) of the Federal Constitution provides that civil courts shall have no jurisdiction in matters that are exclusively within the Shariah jurisdiction. The Court noted that 'the perception that both courts (civil courts and Syariah courts) should exercise a mutually reciprocal policy of noninterference ... maybe somewhat misconceived and premised on an erroneous understanding of the constitutional framework in Malaysia'.

8. ibid 588 .

9. See Eugénie Meriéau, 'Buddhist Constitutionalism in Thailand: When Rājadhamma Supersedes the Constitution', this Special Issue, 298-303.

Io. Gehan Gunatilleke, 'The Constitutional Practice of Ethno-Religious Violence in Sri Lanka', this Special Issue, 359. 
government inaction against, violence against religious minorities, Gunatilleke points to a set of socio-political factors tied to the Sinhala-Buddhist identity that explains ethno-religious violence and, by extension, the breakdown in the rule of law in Sri Lanka. ${ }^{\text {II }}$ In many ways, this piece offers poignant lessons about how such factors could define what the state and society deem 'constitutional' in the country. Returning to the Indira Gandhi case in Malaysia, one has to remember that the issues were set against the backdrop of the expanded role of Islam in Malaysia's constitutional, social, and political orders. The consequence has been the tendency to prioritize 'Islamic' or Muslim interests, often with unfavourable terms and outcomes for minorities.

This gap between text and practice also raises jurisprudential questions. This is particularly evident in the articles on India, the Philippines, and Pakistan. I shall return to the first two examples in the next section, but here I wish to highlight the question of how basic structure jurisprudence shapes religion-state relations - a question mired in constitutional politics. ${ }^{\mathrm{I} 2}$ If the Federal Court in Indira Gandhi invoked the basic structure doctrine to (re)assert judicial power of the civil courts vis-à-vis public (religious) authorities, the Supreme Court of Pakistan - in reviewing a set of constitutional amendments that implicated judicial appointments (and, by extension, judicial independence) - reiterated its power to annul amendments that would alter the Constitution's salient features (including judicial independence). ${ }^{{ }^{3}}$ In doing so, as Nelson argues, the Supreme Court asserts a degree of autonomy in assembling courts that will - at some point in Pakistan's constitutional journey - deal with crucial questions about the role of Islam in its constitutional order. This strategy of carving out an indirect link (via judicial appointments) between basic structure doctrine and religion-state relations is interesting, especially since the Supreme Court of Pakistan has 'pulled away from efforts to constrain the power of parliament via explicit references to "Islam", . 4

In this introductory contribution, I shall bring together the different case studies highlighted in this Special Issue by focusing on two key themes. The first centers on the operation of constitutional arrangements on religion. In this regard, this Special Issue has been carefully curated to highlight a variety of different constitutional provisions on state-religion relations - from India's 'secular' position and the Philippines' American-style separation of church and state, to Afghanistan's arrangement providing Islam as the state religion, along with the injunction that '[n]o law shall contravene the tenets and provisions of the holy religion of Islam'. ${ }^{15}$ Second, I shall synthesize and sketch the factors and conditions that might shape constitutional practice. As we shall see below, there are striking patterns across the different case studies, regardless of their state-religion arrangements. All in all, this contribution is not intended to serve as a comprehensive evaluation of the norms and trends prevalent

\footnotetext{
II. ibid, 369-379.

I2. See Matthew Nelson, 'Indian Basic Structure Jurisprudence in the Islamic Republic of Pakistan: Reconfiguring the Constitutional Politics of Religion', this Special Issue, 333.

I3. ibid 336.

I4. ibid 355 .

I5. Constitution of the Islamic Republic of Afghanistan 2004, arts 2 and 3 (2004 Constitution of Afghanistan).
} 
in the case studies. Instead, I wish to emphasize that in thinking about and understanding the interaction between constitutional law and religion, one has to be mindful of the complex intricacies of socio-political realities in different Asian societies. Laws, policies, and judicial decisions on religion do not emerge in a vacuum; they respond to the evolving needs of society as well as changing political dynamics.

Before delving into the two themes, a short note on the contributions in this Special Issue is necessary. They emerged out of a conference on 'Religion and Constitutional Practices in Asia', jointly organized by the CALS and ICES in Colombo in November 20I7. The conference featured fifteen selected papers broadly divided into three groups: (I) countries with constitutional recognition of Islam; (2) countries with constitutional recognition of Buddhism; and (3) countries without constitutional recognition of any particular religion. Within these groups, the papers addressed a variety of issues including the significance of religion in constitutional history, constitution-making, and constitutional reforms, judicial approaches to resolving religiously-charged cases and the consequence of such approaches, and the ways in which constitutional provisions on religion may directly or indirectly - facilitate societal violence and discrimination. This Special Issue contains seven contributions from the conference, plus four analytical commentaries by seasoned scholars of law and religion. Taken together, these will illuminate an understanding of the prevailing patterns on state-religion relationships, religious freedom, and religious conflict in parts of Asia, and the factors and conditions underlying these patterns.

\section{CONSTITUTIONAL ARRANGEMENTS ON RELIGION: VISIONS, EXPECTATIONS, AND CONSEQUENCES}

Asia is a fascinating laboratory for studies on state-religion relations and majorityminority relationships. At the societal level, the region boasts rich religious diversity, coupled with a high degree of religious observance both in terms of doctrines and rituals. With regard to the legal framework, Asia also presents a broad tapestry of state-religion arrangements that fall somewhere along the secular-theocratic continuum. Some reflect and correspond with the religious demographic of the state, in the sense that there is some form of constitutional privileging of the majority religion. Others adopt a relatively more neutral posturing or attempt to recognize and balance majority and minority religions, despite the presence of a dominant religious group. For example, the Philippines and India adopt a secular arrangement in their constitutions, despite the presence of a strong Catholic and Hindu majority, respectively.

In Muslim-majority states such as Afghanistan, Pakistan, Malaysia, and Indonesia, there are also different permutations on state-religion arrangements. Afghanistan, Pakistan, and Malaysia constitutionalize Islam as the state religion, with religious freedom guarantees for adherents of other religions. However, the 2004 Constitution of Afghanistan and the Constitution of the Islamic Republic of Pakistan 1973 (I973 Constitution) go much further - there are specific injunctions against laws that 
contradict the tenets of Islam. ${ }^{16}$ In Indonesia, where more than 85 per cent of the population is Muslim, there is neither explicit constitutional privileging of Islam nor a repugnancy clause that invalidates laws contrary to Islamic principles, the Quran, or Sunnah. Instead, the Constitution of Indonesia I945 (I945 Constitution) provides that the state 'shall be based on the belief in the one and only God' and guarantees 'the freedom of worship, each according to his/her own religion or belief'. ${ }^{17}$ These different arrangements provide an interesting contrast with the provisions in Buddhist-majority states such as Thailand and Sri Lanka, where the constitutions not only afford special protection to Buddhism, but also attempt to 'balance' this with safeguards for other religions. ${ }^{\text {I8 }}$ Yet, these provisions place positive obligations on the state vis-à-vis Buddhism: in Thailand, the constitution stipulates that the state 'shall have measures and mechanisms to prevent Buddhism from being undermined in any form', while in Sri Lanka, the state has the 'duty' to 'protect and foster the Buddha Sasana'. ${ }^{\text {I9 }}$

The contributions in this Special Issue illustrate that these constitutional arrangements on religion may operate and evolve in unpredictable ways, and they may also, under certain conditions, yield unforeseen (or even perverse) consequences. The issue of unpredictability reverberates throughout Raphael Pangalangan's analysis of the Philippines' American-inspired non-establishment clause. ${ }^{20}$ The heart of the article focuses on the interaction between marriage equality and constitutional commitments on religion, but Pangalangan offers evidence showcasing the persistent influence of a Catholic ethos in statutes, case laws, and state policies. In a similar vein, in Privileging the Powerful, Rehan Abeyratne interrogates the boundaries of constitutional secularism in India ${ }^{2 I}$ by analyzing not the conventional majorityminority dynamics, but rather cases in which competing religious minorities rights were at stake. For instance, in highlighting the Indian Supreme Court's decision in the Shayara Bano ${ }^{22}$ case (widely known as the Triple Talaq case), Abeyratne illustrates how judicial approaches on divisive and politically-charged questions of Muslim personal law have subjugated Muslim women's rights, due to the Court's reluctance to subject personal law to fundamental rights scrutiny and the continuing reliance on the Court's 'essential practices' test. ${ }^{23}$ In another case, ${ }^{24}$ Abeyratne explains the implicit favouring of Hindu dalits over Christian dalits - a situation that has to be understood in the context of India's long-standing battles with religious conversion.

\footnotetext{
I6. See ibid and 1973 Constitution of Pakistan, art 227.

I7. I945 Constitution of Indonesia, art 29(I).

I8. See s 67 of the Constitution of Thailand, Buddhist Era 2560 (adopted on 6 April 2017) (2017 Constitution of Thailand) and art 9 of the 1978 Constitution of Sri Lanka.

I9. ibid.

20. Raphael Pangalangan, 'Relative Impermeability of the Wall of Separation: Marriage Equality in the Philippines', this Special Issue, 415.

2I. The Preamble of the Constitution of India 1950 (I950 Constitution of India) proclaims India as a 'socialist secular democratic republic'.

22. Shayara Bano $v$ Union of India, AIR 2017 SC 4609 (Supreme Court of India).

23. See Rehan Abeyratne, 'Privileging the Powerful: Religion and Constitutional Law in India', this Special Issue, 307.

24. Superintendent of Post Offices $v$ Babu (2007) 2 SCC 337.
} 
The concerns over conversion are not unique to Hindu-majority India. In countries like Malaysia, Myanmar, and Sri Lanka, such concerns also exist, and they have significantly shaped constitutional practices on matters implicating religion. One might recall the package of 'Race and Religion Protection Laws' passed in Myanmar in 2015 , which grew out of apprehensions about conversion (particularly to Islam) and the perceived rapid Muslim population growth. ${ }^{25}$ In Malaysia, the Federal Constitution permits state legislatures to enforce restrictions on the 'propagation of any religious doctrines or beliefs among persons professing the religion of Islam' ${ }^{26}$ In addition, cases such as Lina Joy ${ }^{27}$ and Titular Roman Catholic Archbishop ${ }^{28}$ (the 'Allah' case) demonstrate that anxieties about conversion and proselytism have set the path for an expansion of Islam's role in the constitutional order in ways that would not have been imagined by the country's founding fathers. ${ }^{29}$ If the Federal Court in Lina Joy implied that the right to religious freedom for a Muslim is subject to Islamic principles, in the 'Allah' case the Court of Appeal went further - it declared that the exercise of religious freedom must take into account the position of Islam as the religion of the Federation and that a Minister is obligated to defend the sanctity of Islam in his decision-making. ${ }^{30}$

Gunatilleke's The Constitutional Practice of Ethno-Religious Violence in Sri Lanka showcases a host of unforeseen consequences emerging from the Buddhism chapter in Sri Lanka - consequences that are reminiscent of the Malaysian experience, in particular. It is first worth noting that the conflation of ethnic and religious identities in both countries (ie, the Sinhalese and Buddhism in Sri Lanka, and Malay and Islam in Malaysia) is striking and this conflation has, in many ways, coloured the discourse on religion and constitutional law. Article 9 of the I978 Constitution gives Buddhism the 'foremost place' and places a duty on the state to 'protect and foster the Buddha Sasana, while assuring all religions the rights granted by Articles Io and I4(I)(e)'. What Gunatilleke demonstrates is that this constitutional settlement has been interpreted to outlaw the propagation of other religions as this would 'impair the very existence of Buddhism or the Buddha Sasana'. ${ }^{3 \mathrm{I}}$

The unpredictability of this arrangement is amplified by two competing situations. The first rests in the Sri Lankan Supreme Court's inconsistencies in interpreting Article 9. In a case involving a challenge against the constitutionality of a bill that sought to amend Article 9, the Supreme Court held that the Constitution is secular and that

25. Shameema Rahman and Wendy Zeldin, 'Burma: Four "Race and Religion Protection Laws" Adopted' (The Library of Congress, I4 September 2015) < www.loc.gov/law/foreign-news/article/burma-fourrace-and-religion-protection-laws-adopted/ > accessed Io December 2018.

26. Federal Constitution, art II(4).

27. Lina Joy v Majlis Agama Islam Wilayah Persekutuan [2007] 4 MLJ 585 (Federal Court).

28. Menteri Dalam Negeriv Titular Roman Catholic Archbishop of Kuala Lumpur [20I3] 6 MLJ 468 (Court of Appeal).

29. For an account of the constitution-making history behind art 3 of the Federal Constitution, see Dian AH Shah, Constitutions, Religion and Politics in Asia: Indonesia, Malaysia and Sri Lanka (CUP 20I7) ch 2.

30. Titular Roman Catholic Archbishop (n 28).

3I. Gunatilleke (n Io) 372. 
Parliament may not pass laws that prefer one religion at the expense of another. ${ }^{32}$ Second, this legal regime that affords special status to Buddhism has not only 'perpetuated the entitlement complex of Sinhala-Buddhists'; ${ }^{33}$ it has also - as Benjamin Schonthal astutely observes - empowered and incentivized citizens to engage in legal (constitutional) battles to define the boundaries of Buddhism, how it ought to be safeguarded, and what obligations constitutional arrangements place on the state vis-àvis the privileged or dominant religion. ${ }^{34}$ One would not be hard-pressed to find similar patterns in Thailand and Indonesia, as this Special Issue illustrates, ${ }^{35}$ as well as in other jurisdictions such as Malaysia.

\section{LESSONS: CONTEXTS, FACTORS, AND CONDITIONS}

One of the key objectives of the research project underpinning this Special Issue is to uncover the forces that shape constitutional practices implicating religion. Indeed, the contributions - in varying ways - showcase that legal norms reflect and respond to particular socio-political realities. Likewise, social and political claims may sometimes be traced back to particular constitutional arrangements.

A key issue that pervades the contributions in this Special Issue concerns power balance and dynamics, which are intricately tied to local contexts. These may manifest themselves in quite different ways: be they in the form of competing majority-minority or minority-minority rights claims; in the institution of the Buddhist Kingship (which has legitimated royal intervention in politics and governance); or in state intervention in administering religion and enforcing religious obligations.

In any case, one way to understand the power dynamics at play is by considering the religious demography. The presence of a dominant religious group may trigger certain expectations about the state's behaviour towards the dominant religion. It is also conceivable that governments (and, at times, courts) become conscious about the need to cater for the interests of the dominant religion or to pander to the sensibilities of the main religious group, even if it means disregarding constitutional commitments and the spirit underlying those commitments, as well as notions of justice and legality. Inevitably, these interactions do not just shape a country's constitutional practice, but they also inform the underlying constitutional culture in matters implicating religion.

The Malaysian examples, which are highlighted at various points in this introduction, illustrate how these socio-political interactions between the state and

32. See the discussion on the Nineteenth Amendment Bill case in Jayampathy Wickramaratne, Fundamental Rights in Sri Lanka (2nd edn, Stamford Lake Publication 2006) 933-934. The Nineteenth Amendment Bill sought to impose tighter restrictions on religious freedom by prohibiting, for eg, the conversion of Buddhists into other religions and to install Buddhism as the official state religion. See Nineteenth Amendment to the Constitution (Private Member's Bill), Gazette of the Democratic Socialist Republic of Sri Lanka (29 October 2004), arts 9.I and 9.5.

33. Gunatilleke (n Io) 373.

34. See Benjamin Schonthal, 'Securing the Sasana through Law: Buddhist constitutionalism and Buddhistinterest litigation in Sri Lanka' (2016) 50(6) Modern Asian Studies I966.

35. Meriéau (n 9) and Alfitri, 'Religion and Constitutional Practices in Indonesia: How Far Should the State Intervene in the Administration of Islam?', this Special Issue 389. 
citizens build and reinforce a constitutional culture that treats Islam as a distinct and dominant force in the social, legal, and political spheres. Malay-Muslim claims to priority are conditioned by demographic claims (ie, that the majority religious sensitivities ought to be protected and preferred) and a perverse conception of the constitutional privileging of Islam. In the I980s, religious revival movements - inspired as they were by the Iranian revolution - sought greater adherence to Islamic norms. The government then began pursuing, among others, state-sponsored Islamic symbolism, established institutions (including administrative bodies) to support the development of Islam, used state-sponsored media to propagate the 'official' Islamic doctrine and praxis, and embarked on reforms of Islamic laws nationwide. Though instituted to serve the government's political agenda, these initiatives - coupled with the declaration that Malaysia is an 'Islamic state' - have significantly shaped public psyche and expectations about the constitutional role and force of Islam. A recent case about the National Registration Department's (NRD) decision to attach the patronymic surname 'bin Abdullah' on a Muslim child born out of wedlock is illuminating. The NRD contended, among other arguments, that the decision followed two fatawa issued by the National Fatwa Council in I98I and 2003. Recognizing the injustice and stigma that the child has to bear, ${ }^{36}$ the Court of Appeal held that fatwa does not govern the exercise of the NRD's statutory duties and the decision was thus ultra vires. ${ }^{37}$ Despite the Court of Appeal decision, the NRD announced that it will continue to abide by the edicts of the National Fatwa Council pending an appeal to the Federal Court. ${ }^{38}$

The case studies in this Special Issue offer many interesting parallels. The Philippines' experience is again instructive. In a context where Roman Catholics comprise an overwhelming majority, where the influence of the Catholic Church in politics and policy-making was (and still is) omnipresent, and where much of the country's history and traditions are shaped by over three centuries of Spanish colonial rule (during which Catholicism was the state religion), laws and policies continue to reflect majoritarian preferences. ${ }^{39}$ Alfitri's article on the bureaucratization of Islam in Indonesia also provides further evidence of the state caving in to pressures to proactively manage Islam, implement Islamic law, and enforce Islamic duties against Muslims. On the flip side, there is of course the argument that the demands of efficiency, coordination, and organization meant that state intervention in religious affairs is important, if not necessary. One may find hints of this in the Indonesian Constitutional Court's decision to uphold the constitutionality of laws on Haji and

\footnotetext{
36. It is generally understood within the Muslim community that a child bearing the surname 'bin Abdullah' (when his father's name is not 'Abdullah'), is a child born out of wedlock.

37. See A Child v Jabatan Pendaftaran Negara [2017] 7 CLJ 533 (Court of Appeal).

38. Fernando Fong, 'Home Ministry, NRD to follow National Fatwa Council's ruling on surname of illegitimate children' New Straits Times (Kuala Lumpur, 29 July 20I7) < www.nst.com.my/news/nation/ 2017/07/262043/home-ministry-nrd-follow-national-fatwa-councils-ruling-surname $>$ accessed 2 I December 2018 .

39. However, Pangalangan observes that there are signs of change in selected areas of law. Pangalangan (n 2о) 432-436.
} 
zakat - both of which are part of a Muslim's religious obligations, but are also a lucrative economic enterprise. ${ }^{40}$

This brings me to my second point: the socio-economic dimension of the interaction between law and religion. The bureaucratization of religion or regulation of religion, as the Indonesian scenario demonstrates, presents opportunities for economic benefits. As a corollary, religious observance and the enforcement of religious obligations have become entangled with monetary incentives. In Malaysia, for instance, the federal body tasked to coordinate and spearhead the government's initiatives on Islamic education, administration, and legal policies (JAKIM), received approximately MYR 800 million out of federal coffers in $2018 .^{4 \mathrm{I}}$ Yet, very little is known about its financial accountability. In this regard, the broader questions that Crouch raise about redistribution of wealth, prudent management of a lucrative (religious) industry, and the beneficiaries of this financial gain are apt. ${ }^{42}$ These issues are evident in Alfitri's article, as he highlights various pitfalls in the Indonesian experience with Hajj and zakat management. The recent exposé on misappropriation of Hajj funds by Tabung Haji (a government-linked investment company) in neighbouring Malaysia ${ }^{43}$ also underscores the need to keep tabs on accountability issues surrounding state administration of religion and the economics of religion (and religious enforcement) more generally.

There is yet another facet to the socio-economic story. In societies where religious identities are socially and politically salient - in the sense that they provide a sense of trust, security, and mutual benefit ${ }^{44}$ - competing religious rights claims may be viewed as a matter of group survival. The question of survivability is often painted as a game of numbers tied to political survival: the common story is that the majority (for instance, the Sinhala-Buddhists in Sri Lanka or the Malay-Muslims in Malaysia) are vulnerable in the face of the growing population of minorities, be it through biological reproduction or through proselytism efforts backed by superior financial strength. Hence, the anti-Muslim campaign in Sri Lanka, for example, has not only targeted Muslim practices that are deemed offensive to Buddhist principles and values, but they are driven by fears that Muslim population growth and the building of mosques will eventually displace the country's Sinhalese-Buddhist character. ${ }^{45}$ All these, however, mask deeper socio-economic competition and grievances between majority and minority groups. As Gunatilleke points out, the perceived Muslim dominance in

40. Alfitri (n 35) 398-401, 405-406.

4I. Shazwan Mustafa Kamal, ‘At RM8 Iom, is Jakim's budget bloated? New minister says no' (Malay Mail, 7 July 20I 8) < www.malaymail.com/s/I64972 I/at-rm8 Iom-is-jakims-budget-bloated-new-minister-saysno $>$ accessed 2I December 2018.

42. Melissa Crouch, 'Constitutionalism, Religion, and Inequality: Perspectives from Asia', this Special Issue, 239.

43. 'TH lodges police reports against former Chairman, CEOs and senior management' The New Straits Times (Kuala Lumpur, 30 November 20I8) <www.nst.com.my/business/20I8/II/436I 56/th-lodgespolice-reports-against-former-chairman-ceos-and-senior-management $>$ accessed 20 December 2018.

44. Donald L Horowitz, 'Democracy in Divided Societies' (I993) 4(4) Journal of Democracy I 8.

45. See Center for Policy Alternatives (CPA), 'Attacks on Places of Religious Worship in Post-War Sri Lanka' (CPA March 20I3) 60 <www.cpalanka.org/attacks-on-places-of-religious-worship-in-post-war-srilanka/ $>$ accessed December 2018 . 
business and trade are seen as a threat to the economic prosperity of the SinhalaBuddhists. ${ }^{46}$

Finally, the articles in this Special Issue exemplify the continuing salience of religion in politics and the implications of the politicization of religion. Shamshad Pasarlay's article illustrates how the politics of religion have shaped constitution-making processes and the outcomes of those processes in Afghanistan. ${ }^{47}$ Similar patterns are evident in Sri Lanka, Thailand, and Indonesia, although there are nuances in degree, process, and outcomes. Indeed, despite facing comparable social and political constraints, the constitution-makers in these countries opted for very different paths in constitutionalizing religion.

I have briefly alluded to the influence of the Iranian revolution on the Malaysian social and political landscape, prompting political elites to appeal to the groundswell of Islamic nationalism. In Indonesia, the Soeharto administration - initially deeply suspicious of political Islam - also began to demonstrate its commitment to Islamic interests. The impact of political Islam and the politicization of Islam was magnified after the fall of Soeharto in I998, as evident in the enactment of various 'shariah-based legislation', including Law No 38 of 1999 on Zakat Management (I999 Zakat Management Law). ${ }^{4}$ Meanwhile, religiously-inspired regulations - either explicitly labelled as shariah regulations (perda syariah) or clothed as public order regulations also proliferated at the local level. ${ }^{49}$ The precise contents of the regulations vary across different localities, but in general they cover issues of morality, dress, religious 'deviance', and religious practices, often with injunctions ordinarily associated with Islam. In some provinces and districts, regulations also seek to compel Muslims to perform particular religious obligations and practices, with the aim of enhancing piety. The great paradox about these developments is that they have flourished in the democratic environment and relatively freer political space that emerged after Soeharto's departure. Local politicians running for office have not - for reasons of political expediency - been able to ignore the pressure by conservative, or even fundamentalist, groups. Working, in some cases, with local Majelis Ulama Indonesia (MUI) chapters, these organizations have been involved in drafting regulations, lobbying political elites for approval of the draft regulations, and mobilizing societal support. There are known cases in which agreements were struck with influential local clerics for votes from their followers in exchange for promises that the candidates, once elected, will pursue particular policies on religion. ${ }^{50}$

\footnotetext{
46. Gunatilleke (n Iо) 375.

47. Shamshad Pasarlay, 'Constitutional Incrementalism in a Religiously Divided Society: A Case Study of Afghanistan’, this Special Issue, 255.

48. Alfitri (n 35) 410 .

49. A study finds that there are at least 400 of such shariah regulations in Indonesia. Approximately $40 \%$ of these regulations are couched in terms of regulating 'morality', while $60 \%$ address 'Islamic teachings'. See Michael Buehler and Dani Muhtada, 'Democratization and the diffusion of shari'a law: Comparative insights from Indonesia' (20I4) 24(2) South East Asia Research 26I, 266. See also Michael Buehler, The Politics of Shari'a Law: Islamic Activists and the State in Democratizing Indonesia (CUP 20I6).

50. See Shah (n 29) I30-I3I.
} 
This example, and others in this Special Issue, showcase the potential for the politicization of religion to stifle religious harmony, the development of a vibrant religious discourse, and the protection of fundamental rights.

\section{CONCLUSION}

The commentaries and articles in this Special Issue present rich food for thought. As countries in the region undergo political change and consolidate constitutional democracy, they will continue to grapple with questions about the parameters of rights, managing delicate ethnic and religious relations, balancing freedoms with the protection of public order, and strengthening rule of law institutions. A freer political space facilitates the proliferation of ideas, opinions, and discourses not only about the role of religion in the state, but also about the fundamental norms of the polity. As this Special Issue illustrates, many of the most divisive issues arise from competing visions and understandings about religious freedom and constitutional commitments on religion. At a positive level, this reflects a broader, ongoing process of constitutional interpretation to shape the dominant norms governing a country. However, in some instances, they evince a growing pattern of utilizing constitutional arrangements in ways that yield to majoritarian demands, state prerogatives, or both, especially in cases in which an issue or dispute involves - directly or indirectly - a 'contest' between majority and minority interests.

Beyond the issues that I have raised in this article, there is another important point that echoes through the contributions in this Special Issue: the role of social movements and mobilization in shaping constitutional practices implicating religion. This underscores the point that constitutionalism and constitutional practice are a bottom-up affair as much as it is top-down. This thus forces us to confront the reality that in many Asian societies, non-state actors maintain a pervasive influence on religion and law (both in terms of law-making and law enforcement). The questions, then, are how states approach and recalibrate their relationships with such actors and their demands, and what implications might bear on the rule of law and constitutionalism. Again, Asia offers a fertile ground for studies on these questions, especially in light of changing domestic political landscapes. 